\title{
The impact of Industry 4.0 on the selected macroeconomic indicators in Slovak Republic, Germany, the USA and Japan
}

\author{
Jozef Habánik \\ Faculty of Social and Economic Relations, \\ A. Dubceet University of Trencinn, \\ Slovak Republic \\ jozef.babanik@,tnuni.sk
}

ORCID 0000-0001-7898-2735

\author{
Adriana Grenčíková \\ Faculty of Social and Economic Relations, \\ A. Dubřek University of Trenčn, \\ Slovak Republic \\ adriana.grencikova@tnuni.sk \\ ORCID 0000-0003-1077-1127 \\ Karol Krajčo \\ Faculty of Social and Economic Relations, \\ A. Dubcée. University of Trenčn, \\ Slovak Republic \\ karol.krajco@,tnuni.sk \\ ORCID 0000-0002-7698-6078
}

Abstract. Rapid development of communication and information technologies with their orientation on big data have significantly changed the character and the needs of national economies. The onset of the 4th Industrial Revolution significantly affects the structural changes of individual economies (companies) as well as their requirements for workforce. The Industry 4.0 concept was created in Germany, and now is being implemented in various countries under different names. In our study, we focus on the development of the selected macroeconomic indicators in Slovak Republic as compared to other selected countries (Germany, USA and Japan). The countries above are traditionally considered to be the drivers of innovation. The aim of this study is the analysis of trends in macroeconomic indicators of these economies so that to derive recommendations for future workforce preparation. The analyzed indicators are GDP growth rate, employment development, labor productivity, value added, expenditure on science and research and education.

Received: July, 2020

1st Revision: February, 2021

Accepted:

May, 2021

DOI:

$10.14254 / 2071$

$8330.2021 / 14-2 / 2$ 
Keywords: Industry 4.0, GDP, labour productivity, employment, education, added value.

JEL Classification: F63, O31, O51

\section{INTRODUCTION}

Industry 4.0 is a relatively new industry concept that will greatly affect the life of society in all respects. It reflects the social change brought about by the interconnection of the physical, virtual and social worlds, and it affects many areas at the same time - industry, technical standardization, security, education, legislation, research, social systems, labour market, working conditions, labor qualification requirements and the like. The concept of Industry 4.0 appeared back in 2011 in Germany (Slusarczyk, 2018). Cyber-physical systems, the Internet of Things (IoT), cloud and cognitive computing are the main elements of this concept (Hozdic, 2015; Slama, Puhlmann, Morrish \& Bhatnagar, 2016). In Germany, two models were developed to digitize industrial production. These models are called the Reference Architecture Model Industry 4.0 (RAMI 4.0), and the Industry 4.0 Component Model. They are currently considered to be the most important models for the purposes of Industry 4.0 (Zezulka et al., 2016). The most significant impact of the fourth industrial revolution is expected to be reflected in employment and economic growth. The ability of an economy to adapt to technological changes, whether current or expected, is determined by several factors, one of which is country's innovation level. The innovation level of a country is understood as a complex of several factors, including mainly the educated workforce, the quality of $\mathrm{R} \& \mathrm{D}$, funding intensity, but also some output indicators, such as the share of intensive industries in the structure of the economy, employment rate, export volumes, the level of intellectual property production and the like. Since the Second Industrial Revolution, R\&D has been playing a very important role in innovation and technological advances. Therefore, there is a presumption that $\mathrm{R} \& \mathrm{D}$ system performance as well as intensity of participation in the international R\&D system will be particularly important for the development of Industry 4.0 within national borders. The Fourth Industrial Revolution is also often called the "path to an innovative economy" because its digital connections will not only improve efficiency but also accelerate innovation and introduce new business models that could be implemented much faster (Industry4.0.sk). Changes related to the implementation of the Industry 4.0 concept should have a positive impact on the competitiveness of enterprises, increasing production flexibility, and generally gaining a better position for the companies on the market thanks to their higher efficiency (Industry4.0.sk). The introduction of new technologies and the consequent need to retrain workers will ensure an increase in workers' human capital, which also creates multiplier effects on innovation, competitiveness, economic development and growth (Solarin, 2016; Hatemi-J, 2016; Zaccaria, 2016). Slovak economy is one of the most efficient ones in the EU. The focus of this economy on the automotive industry assumes that the introduction of Industry 4.0 under Slovak conditions would be necessary. For this reason, comparison of the selected indicators with the similar indicators of such strong economies such as Germany, USA and Japan brings new results and findings that have not yet been published, to the best of our knowledge. We assume here that the indicators we have chosen are most influenced by the implementation of the Industry 4.0 concept. The influence of Industry 4.0 on the monitored indicators has not been investigated in the publications available and indexed in the international scientific databases (Web of Science, Scopus). Correlation analysis confirmed the strong dependence of the examined indicators. 
The paper is organized as follows. First, we present a short theoretical literature review on the concept of Industry 4.0 as well as on the selected macroeconomic indicators. It is followed by the methodology part that explains the research context, data collection methods and data analysis. After that, we discuss the results of the analysis of the selected indicators in the period of the Industry 4.0 concept implementation in the monitored countries. Finally, we present some directions for future research as well as recommendations for practice. The main assumption of our study is that the impact from the introduction of Industry 4.0 in the economy causes an increase in the overall performance of the economy with a slight delay, as well as an increased need for expenditures on science and research.

\section{LITERATURE REVIEW}

It follows that the more goods people produce, the more they can consume them. Several factors influence the level of labor productivity and the rate of economic growth (Lisý, 2011). A prerequisite for achieving an optimal rate of economic growth is the free, equal status of political and economic institutions. Only a free economy and a democratic state can create the preconditions for such a dynamic economic development that ensures abundance of goods for all citizens (Lisý, 2005). Sources of economic growth consist essentially of changes in inputs and technology used in the production of goods. On the basis of this, the sources of economic growth can be divided into two groups - either the sources of extensive economic growth or the sources of intensive economic growth. This breakdown results from the fact that economic growth can essentially be achieved in two ways (Uramová, 2010): increasing the amount of resources used, ie extensive, better use of existing resources due to technical, technological or organizational improvements, ie intensive. An important source of economic growth is the economic activity of people, which has its origin in human freedom. A person's personality, goals, actions, motives and decisions are one of the most important factors of growth. According to A. Smith (in Lisý, 2011), by knowing the causes and sources of wealth and then acting, they can extend freedom to economic activities. The source of the wealth of nations is economic freedom manifested in human creativity, entrepreneurship, people's initiative and activities, both a fundamental prerequisite and a driver of economic growth. Developing the ideas of A. Smith, the present American economist M. Novak concluded that the source of the dynamism of the economy is entrepreneurship, which is a product of human reason. The impact of Industry 4.0 will therefore be reflected in the labor market, which will undergo significant changes. Changes will occur in the types of occupations, in the structure of the labor market as such, in professional profiles of workers, in competency models of job positions and the like (Kordoš, Vojtovič, 2016). Some old jobs and professions will disappear completely and replace them with new ones, so the risk of losing jobs is increased for people with low skills and low digital skills (Pinzone, Fantini, Perini, Garavaglia, Taisch, Miragliotta, 2017). Professions that will not be able to be digitized in the foreseeable future, in particular management positions in the district, health, education, social services and the like, will be least affected. Personnel selection will be dominated by a high degree of docility (LQ Learnability Quotient), emphasis will be placed on the talent and created a system of continuous human resource development. Businesses implementing Industry 4.0 will need to be so-called "learning organizations" and business management will implement knowledge management (Záležáková, 2018). A question that is beginning to be strongly debated is the preparation of the workforce for these labor market needs. According to a study carried out by the Government of Germany, 500000 jobs are expected to disappear as a result of the changes, while 900000 new jobs are expected to be created at the same time. The problem is that no one can define the job description of new jobs well enough, and it follows that neither the requirements for the job holders can be defined, so we cannot define the requirements for the preparation of the workforce. Let us assume that one of the main ideas of the 
Industry 4.0 concept is the greatest possible personalization of products according to customer requirements. We assume that this will create many specialized jobs and many requirements for specialization in education. For this reason, a wide-ranging education will be required and the role of the employer will be to train specialists according to their requirements (Hiete, Ludwig, Schultmann, 2012).

The most important factor affecting the standard of living and the rate of GDP growth is labor productivity, which is the amount of goods produced per employee in one hour of work. Today, new knowledge and expertise in science and technology is advancing at a rapid pace, as a result of which the economy is overly dependent on knowledge and innovation. Not only the competitiveness of manufacturing companies but also the streamlining of production and innovation leads to an increase in labor productivity. Productivity expresses how efficiently products have been produced or services provided on the basis of the use of all resources, new approaches and systematic improvement of methods (Rievajová, 2017).

\section{METHODOLOGY}

In our study, we have focused on the development of selected macroeconomic indicators in the Slovak, Germany, USA and Japan. These countries are considered to be drivers of innovation. The aim of the study is based on the analysis of the development of trends in macroeconomic indicators in these economies to derive recommendations for the preparation of the workforce.

\section{Data Collection}

We have been set sub-goals to meet the goal. We have analyzed time series of selected macroeconomic indicators, which we considered to be most influenced by the Industry 4.0 concept. These were the following indicators: economic growth, employment, labor productivity, added value. We have analyzed the area of expenditure on science and research, education as well as the share of university graduates in total employment. It is these indicators that are a prerequisite for the intensity of innovation. We have used time series analysis, linear regression, descriptive statistics and comparison. Correlation analysis is based on the idea, that the straight line may connect data points. In such a case, the correlation coefficients and the linear regression coefficients just reflect this idea. For the analysis of our data such methodology in some cases is acceptable, but in some is not. A polynomial regression and percent of the moving average was utilized to show the change in the dependent variable $\mathrm{Y}$ from the change of the independent variable X. A polynomial model is suitable for some of our data analysis. The main source of information is the study of primary and secondary sources. Data were obtained from official statistics of OECD, Eurostat and UNESCO. We have determined the years 1995-2018 for the observed period. If data were not available, we have used data for years in which data were available for all countries surveyed.

\section{EMPIRICAL RESULTS AND DISCUSSION}

According to OECD data in the countries surveyed, we conclude that GDP growth at constant prices was the highest in the Slovak Republic, GDP increased by 169.39\% from 1993 to 2018. The second highest increase in absolute value GDP reached the United States (87.29\%), Germany had an increase of $44.09 \%$. Japan had the smallest increase in the period under review $(26.83 \%)$.

The graph below shows the development of the GDP growth rate from 1995 to 2018. Based on this development, the Slovak economy reached the highest average GDP growth rate (4.09\%). Japan had the lowest average value $(0.97 \%)$, with an aging population beginning, the United States at an average rate of $2.55 \%$, and Germany at $1.49 \%$ over the period under review. 


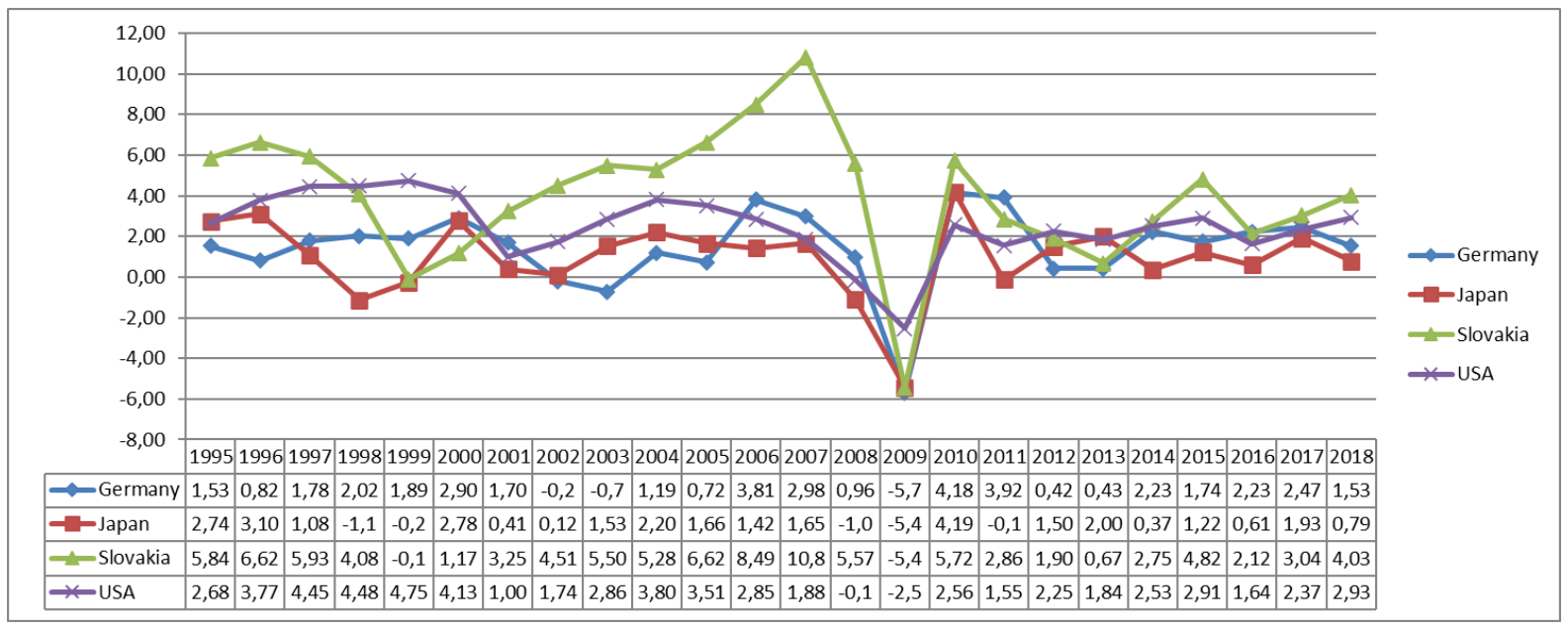

Graph 1. Growth rate of GDP in $1995-2018$ (\%)

Source: OECD, own calculation.

During the reporting period, Japan had an economic downturn in up to five reference years $(-1.13 \%$ in $1998,-0.25 \%$ in $1999,-1.09 \%$ in $2008,-5.42 \%$ in 2009 and $-0.12 \%$ in 2011$)$. As a result of the financial and economic crisis in 2009, all economies under review recorded an economic downturn, with the United States (Germany -5.7\%, Slovak Republic -5.46\%, Japan -5.42\%, United States -2, 54\%). During this period we can observe a decline in employment in all countries. The development of employment is shown in Graph no. 2.

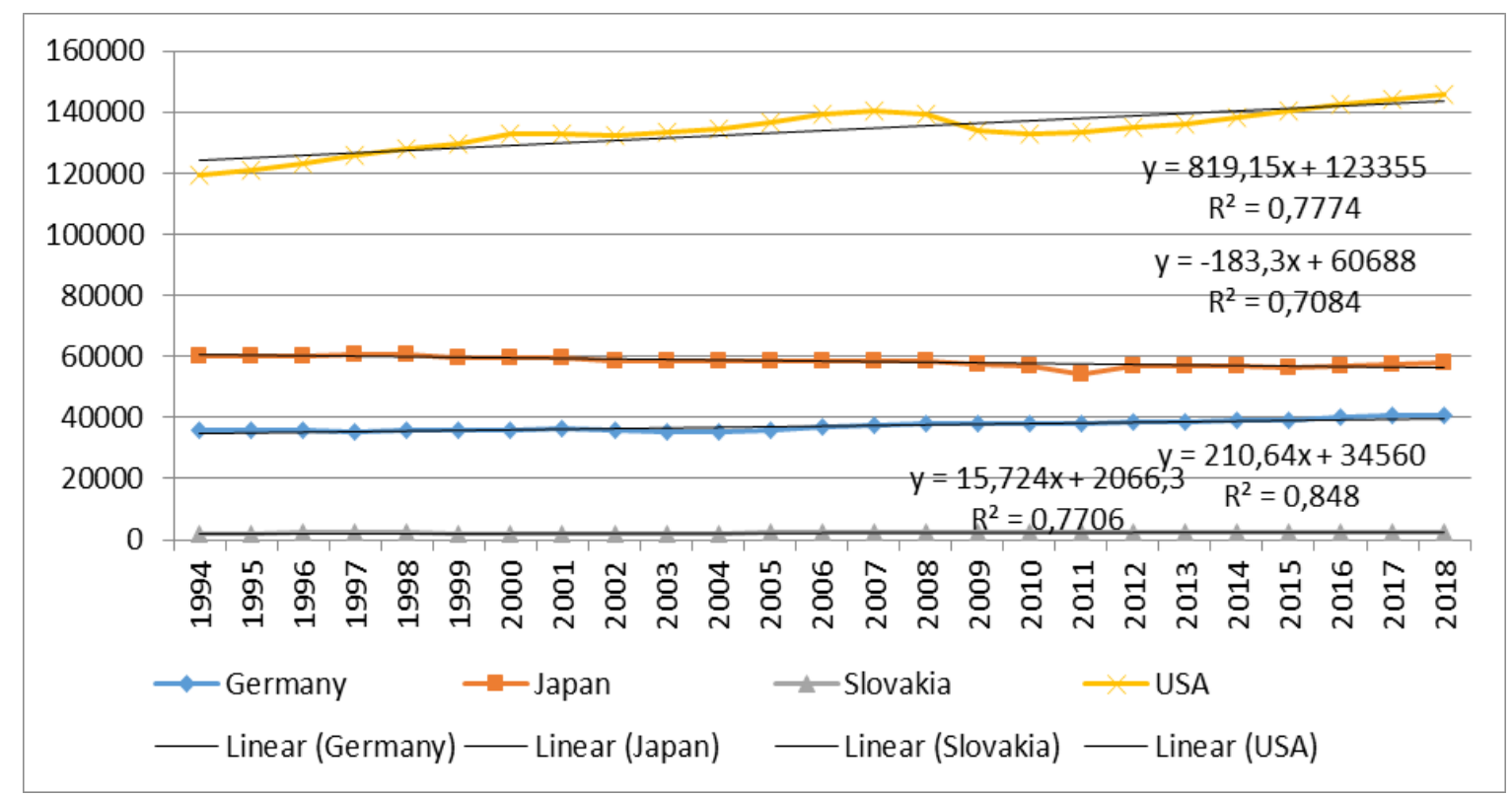

Graph 2. Employment and its linear trend in 1994-2018 (persons in thousand) Source: OECD, own calculation. 
As regards employment, we note that Japan was the only one to have seen a decrease in the number of employed in 2018 compared to 1994 (-3.71\%). All the other countries surveyed achieved a higher number of employed, with the percentage change as follows: $33.63 \%$ USA, 20.54\% Slovak Republic, $13.34 \%$ Germany. In the long term, after inserting a linear trend of employment development into the graph, growth of employment in USA, Germany and Slovakia can be expected. Based on the compiled equations, we can state that the prognosis of positive development in this area will be the highest in the case of the USA (the value of $\mathrm{X}$ variable is $819.15 \mathrm{x}$ and the value of intercept $\mathrm{b}_{0}=123355$ ). Germany will be the second fastest growing country (the value of the $\mathrm{X}$ variable is $210.64 \mathrm{x}$ and the value of the intercept $\mathrm{b} 0=34560$ ). Slovakia will be the third growing country (the value of the $\mathrm{X}$ variable is $15,724 \mathrm{x}$ and the value of the intercept $\left.b_{0}=2066,3\right)$. The linear trend equation confirms the decline in employment in Japan (X variable $-183.3 \mathrm{x}$ and intercept $\mathrm{b}_{0}=60688$ ). Reliability of this statement is 0,848 (Germany), 0,7774 (USA), 0,7706 (Slovakia) and 0,7084 (Japan).

In our analyzes, we were interested in the impact of the educational level of the population on the performance of individual economies. In the following graph no. 3 shows the share of university graduates in the total employment. The linear trend is increasing for Germany and Japan throughout the period under review. The opposite trend can be observed in the United States and the Slovak Republic. The highest decrease is observed in the Slovak Republic, with the linear trend having the equation $y=$ $0.3994 \mathrm{x}+88.516$ with a reliability $\mathrm{R}^{2}=0.7775$. In the long term, in all the countries under review, including Slovakia, linear weekly equations predict an increase in the share of university graduates in the total number of employees.

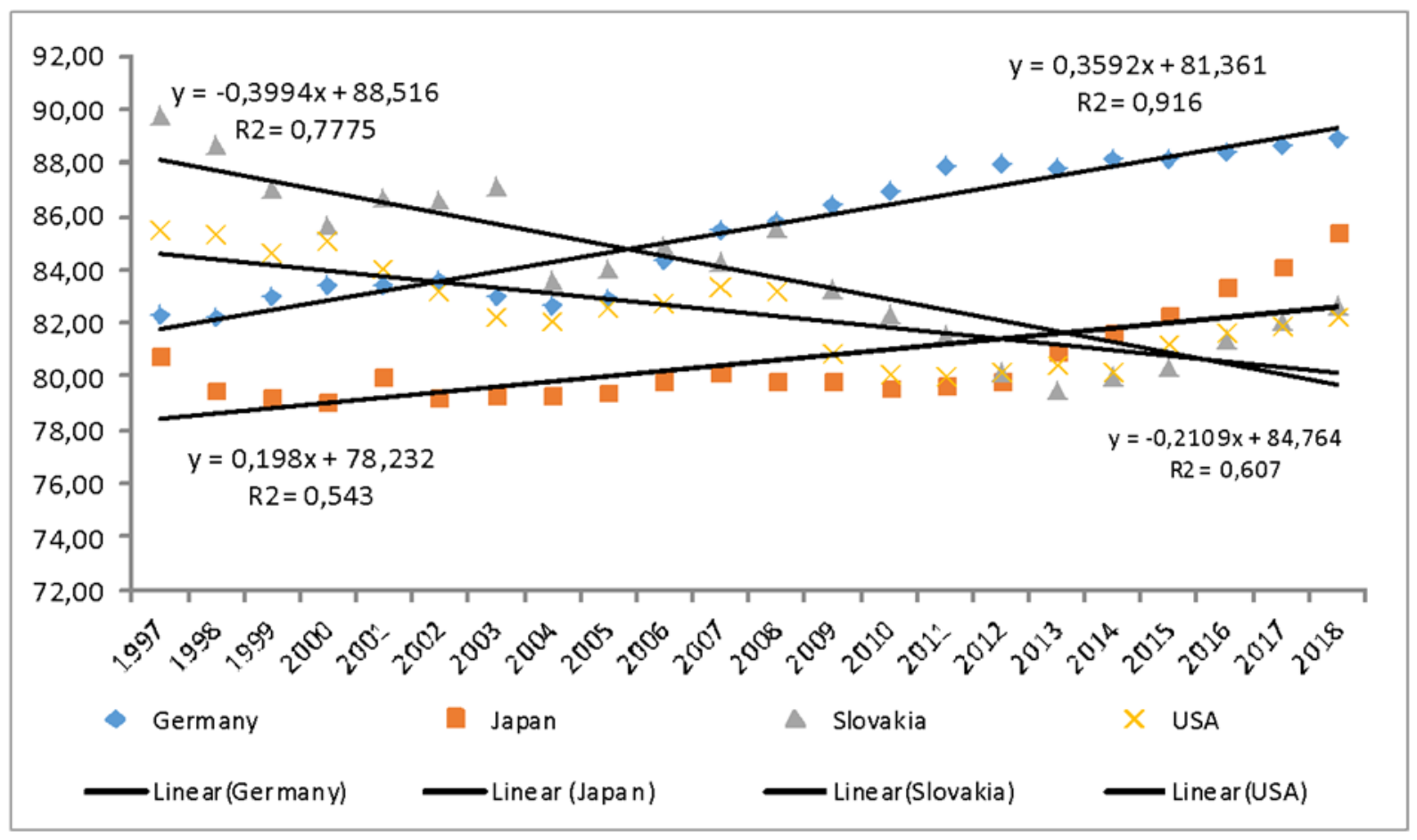

Graph 3. Share of university graduates in the total employment (\%) - linear trends Source: OECD, own calculation. 
We have seen growth in the share of university educated employees in all countries since 2013. In the last available year, the data confirmed that the gap between the countries under review has narrowed. In 2018 Germany, the share increased by 6.61\% compared to 1997, in Japan the share increased by $4.65 \%$. In 2018, Slovakia and the United States decreased their share in the Slovak Republic by $-7.12 \%$ and in the USA by $-3.19 \%$. In both cases, at the beginning of the reporting period, these countries had the highest share of university graduates (Slovakia $89.76 \%$, USA $85.40 \%$ ). Based on a linear trend from the compiled equations, we can state that the forecast of positive development in this area will be only in the case of Japan and Germany. Faster growth will be in Germany (value of X variable is 0.3592x and value of intercept $\mathrm{b}_{0}=81.361$, reliability 0.91 ). Japan will be the second fastest growing country (the value of the $\mathrm{X}$ variable is $0.198 \mathrm{x}$ and the value of the intercept $\mathrm{b}_{0}=78.232$, low reliability 0.543 ). Slovakia will decline due to the negative value of $\mathrm{X}$ variable $\left(-0.3994 \mathrm{x}\right.$, intercept $\mathrm{B}_{0}=88.516$, reliability 0.7775$)$ faster than the USA ( $\mathrm{X}$ variable is $-0.2109 \mathrm{x}$, intercept $\mathrm{B}_{0}=84.764$, low reliability 0.607 ). In this case, the reliability value was low, so for clarity, we add graph 4 with a polynomial trend. In the case of a polynomial trend, a positive growth trend can be expected in all surveyed countries in this area. The Slovak Republic achieved a turning point in the polynomial trend in 2014. Since 2014, there has been a positive growth trend. The ranking of countries based on the polynomial trend of this indicator in the following period is as follows: Japan, USA, Slovakia and Germany.

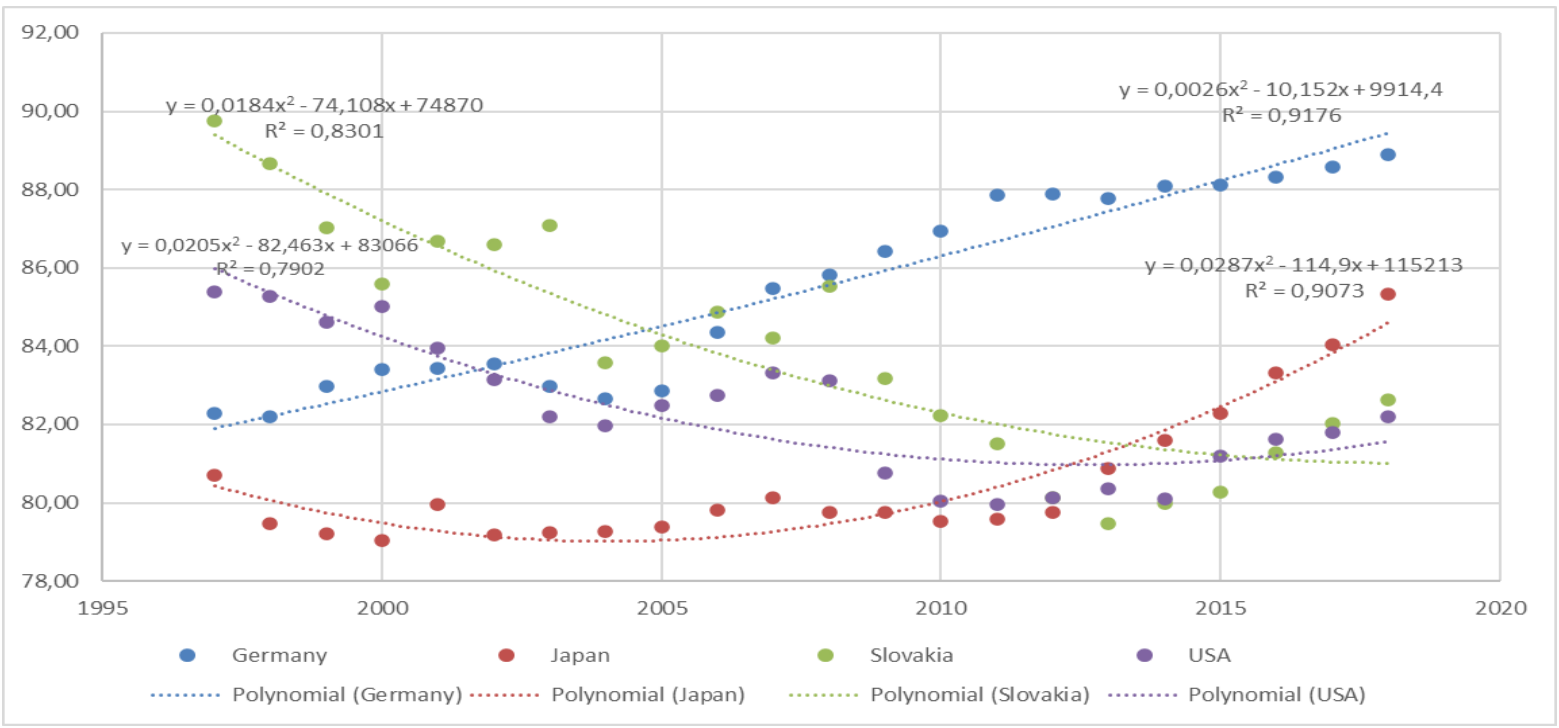

Graph 4. Share of university graduates in the total employment (\%) - polynomial trends Source: OECD, own calculation.

In the area of state expenditure on science and research, the Slovak Republic lags significantly behind the other countries under review. Development expenses are presented in the graph 5 .

In spending, Germany increased total R\&D expenditure by $42.91 \%$, Japan by $27.60 \%$ and the USA by $19.78 \%$. The Slovak Republic increased spending by $0.61 \%$, Japan is the highest at the end of the period under review, the share of GDP in GDP is 3.21\%, the second is Germany with 3.04\% and the third US with $2.79 \%$. It is clear from the graph that, except for Slovakia, all states increased their share of expenditure in the period under review. 


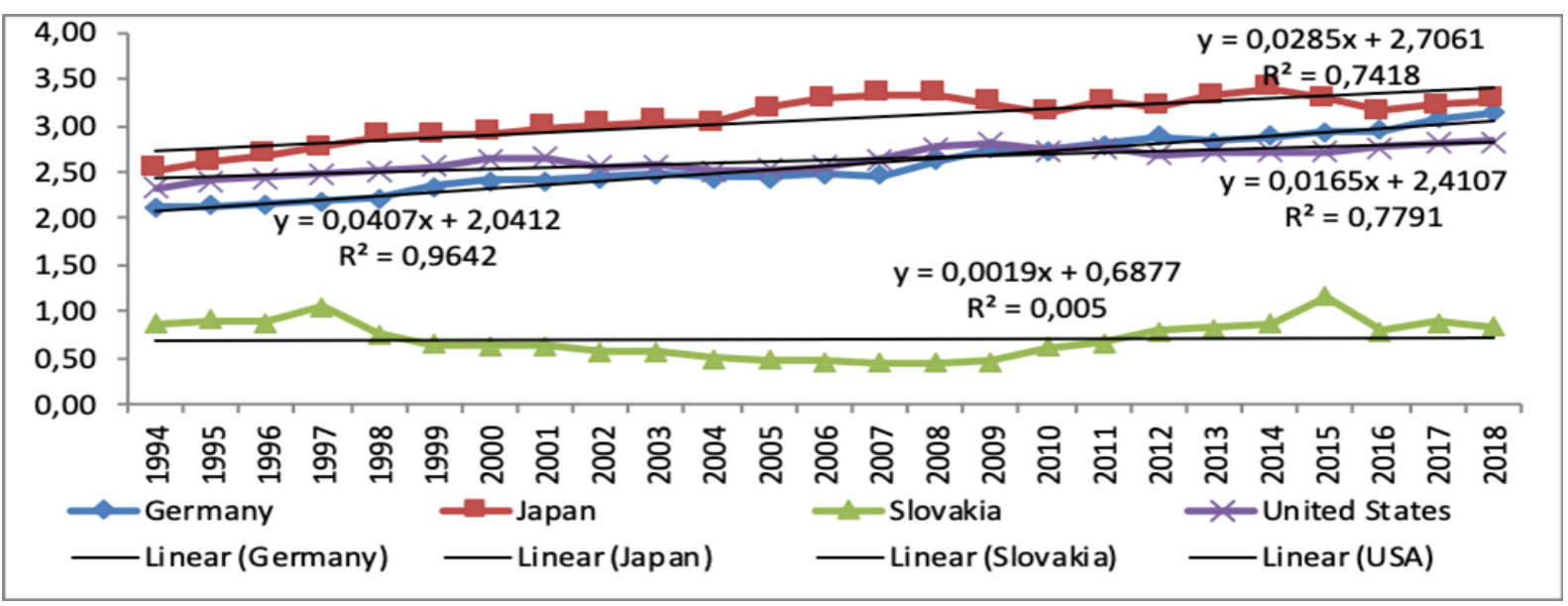

Graph 5. Development of R\&D expenditures and their linear trend (share in GDP in \%) Source: OECD, own calculation.

The Slovak Republic did not increase the share, on the contrary the share decreased steadily from 1998 to 2007 , reaching only $0,44 \%$ of GDP in 2007. At the end of the period under review, Slovakia had expenditure of $0.84 \%$ of GDP. The long-term linear trend also assumes growth in this indicator. In the case of the Slovak Republic, this growth is almost zero, since $\mathrm{r}^{2}=0.0005$.

Table 1 shows the available data on government expenditure on education as a percentage of GDP. In the available statistical databases, data are only available for the period 2010-2016 for Germany and the Slovak Republic.

Government expenditure on education as a percentage of GDP

Table 1

\begin{tabular}{|l|l|l|l|l|l|l|l|}
\hline & $\mathbf{2 0 1 0}$ & $\mathbf{2 0 1 1}$ & $\mathbf{2 0 1 2}$ & $\mathbf{2 0 1 3}$ & $\mathbf{2 0 1 4}$ & $\mathbf{2 0 1 5}$ & $\mathbf{2 0 1 6}$ \\
\hline Germany & 4,91 & 4,81 & 4,93 & 4,93 & 4,93 & 4,81 & 4,80 \\
\hline Japan & 3,64 & 3,64 & 3,69 & 3,67 & 3,59 & $\mathrm{n} / \mathrm{a}$ & $\mathrm{n} / \mathrm{a}$ \\
\hline Slovakia & 4,12 & 3,96 & 3,91 & 4,09 & 4,23 & 4,64 & 3,90 \\
\hline USA & 5,42 & 5,22 & 5,19 & 4,94 & 4,99 & $\mathrm{n} / \mathrm{a}$ & $\mathrm{n} / \mathrm{a}$ \\
\hline
\end{tabular}

Source: UNESCO, Eurostat, own processing.

The above table shows that the share of expenditure on education differs between the countries under review. Germany and Japan did not significantly change the share of education expenditure as a share of GDP, and the changes in the reference years did not exceed 0.1 percentage points. The USA recorded the most significant decline. Apart from 2015, the Slovak Republic oscillated at 4\% of GDP. Compared to the absolute value of GDP and the share of education, it is necessary to state that also in this indicator the Slovak Republic is the last of the monitored countries. It is necessary to realize that in the case of the Slovak Republic, GDP is 23 times lower than Germany's, 29 times lower than Japan's and 109 times lower than in the USA. Therefore, despite the relatively similar percentage of expenditure on education on GDP, the difference in absolute values is significant.

In the following graph 6 we examine the development of labor productivity in the national economy, expressing the value of GDP created by employment. The highest percentage increase in the value of production per one employed was achieved by the Slovak Republic (110.43\%). The second highest 
percentage growth was achieved by the USA (47.16\%), the third by Japan (30.41\%) and the last by Germany $(24.15 \%)$.

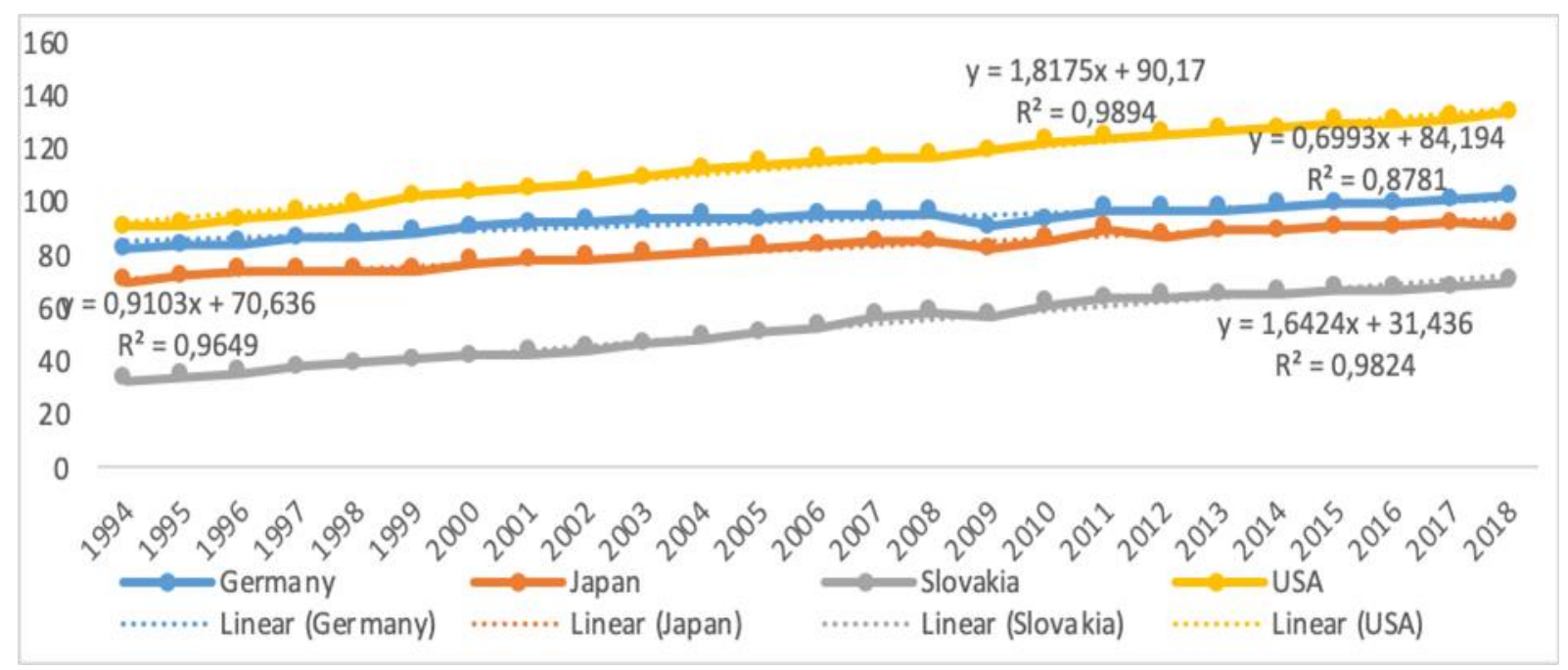

Graph 6. Value of GDP created by employment and its lineat trend (in USD thousands) Source: OECD, own calculation.

In absolute terms, employee productivity was highest in the USA. Productivity at the end of the period under review was 133.62 thousand. This represented an increase of 42,821 thousand USD Germany increased its product per employee by 19,832 thousand USD from 82.11 thousand USD to 101.94 thousand USD. Japan from 70,156 thousand USD to 91,494 thousand USD, which represents an increase of 21,338 thousand. USD. All the countries under review grew on the basis of a linear trend in the period under review and this growth is foreseeable also in the following period, which is also supported by high levels of reliability. Productivity growth was also not affected by the global financial and economic crisis, although there was a slight decline in 2009 and 2010. It should be noted that a decline in GDP as well as a decline in employment during this period may lead to a positive increase in productivity, which is reflected in productivity levels also in the years following the crisis and negative labor market developments. The linear trend used in this case shows high reliability in all countries (Germany 0.878, Japan 0.964, Slovakia 0.982, USA 0.989). Based on the compiled equations of linear regression, we can assume growth in all countries. The order of countries in positive growth will be as follows: USA (X variable 1.8175x, b0 $=90.17)$, Slovakia $(\mathrm{X}$ variable $1.6424, \mathrm{~b} 0=31.436)$, Japan $(\mathrm{X}$ variable $0.9103, \mathrm{~b} 0=70.636$ ) and Germany $(\mathrm{X}$ variable $0.6993, \mathrm{~b} 0=84.194)$.

We subjected the above-monitored macroeconomic indicators to a correlation analysis. Based on the results, we can state that in all countries there is a strong positive correlation between the indicators. The exception is Japan, where the correlation of employment on the monitored indicators is weak, in the case of GDP and productivity negative. The results are shown in Table 2. 
Results of correlation analysis of investigated indicators

\begin{tabular}{|c|c|c|c|c|c|c|c|c|c|}
\hline \multicolumn{5}{|c|}{ Slovakia } & \multicolumn{5}{|c|}{ Japan } \\
\hline & $G D P$ & Value added & Productivity & Employment & & $G D P$ & Value added & Productivity & Employment \\
\hline GDP & $x$ & & & & GDP & $x$ & & & \\
\hline Value added & 1,00 & $\mathrm{x}$ & & & Value added & 0,97 & $x$ & & \\
\hline Productivity & 0,97 & 0,98 & $x$ & & Productivity & 0,83 & 0,70 & $x$ & \\
\hline \multirow[t]{3}{*}{ Employment } & 0,74 & 0,74 & 0,57 & $x$ & Employment & $-0,06$ & 0,13 & $-0,61$ & $x$ \\
\hline & & Germany & & & & & USA & & \\
\hline & $G D P$ & Value added & Productivity & Employment & & $G D P$ & Value added & Productivity & Employment \\
\hline GDP & $x$ & & & & GDP & $x$ & & & \\
\hline Value added & 1,00 & $x$ & & & Value added & 1,00 & $x$ & & \\
\hline Productivity & 0,92 & 0,92 & $x$ & & Productivity & 0,92 & 0,91 & $x$ & \\
\hline Employment & 0,93 & 0,93 & 0,71 & $x$ & Employment & 0,66 & 0,67 & 0,30 & $x$ \\
\hline
\end{tabular}

Source: OECD, own calculation.

\section{CONCLUSION}

Based on the analysis of selected indicators, it can be stated that since its inception in 1993 the Slovak Republic has seen a positive development trend from a macroeconomic point of view. The Slovak Republic is an equal partner in most indicators to strong traditional economies such as the USA, Japan and Germany. It is necessary to realize that the Slovak economy outperformed these economies at the rate of growth of indicators, but this fact is given by the starting point of the establishment of the independent Slovak Republic. Since its inception, the Slovak Republic has had to converge to advanced economies, whether real or nominal. In terms of nominal convergence, the Slovak economy can be considered as mature and competitive. (Ivanová, Masárová, 2018). From the point of view of real convergence, there is still time to get the Slovak economy closer to developed countries such as the USA, Japan and Germany.

State spending on education, as well as science and research, is very low compared to the countries under review. It is also necessary to realize that the share of expenditures on science and research, but also on education in comparison with the absolute amount of spent funds is a great threat to the future of the Slovak economy on the labor market as well as on the product and services market itself.

This is confirmed by several studies that show the results of the analysis, which showed that the impact of Industry 4.0 is likely to significantly reduce employment, so that some jobs completely disappear and the labor market new jobs, ie the education system will be forced constantly to adapt to new conditions and requirements, ie to transform and professionalize. It will also be necessary to permanently provide for retraining and training of workers. The most demanded will be people with technical focus, research and development workers, workers in the field of individual production phases and operators, whose competence will be supervision and coordination of production processes (Niková, 2018). If manual work is replaced by robots, machines and equipment, it is structural and involuntary unemployment. It is anticipated that in the next five to ten years, monotonous work will be replaced by machines and these people will therefore become unemployed. In China, for example, up to 60,000 people were released in May 2016 as a result of digitization and robotization. At that time Foxconn decided to replace human labor with machines to reduce labor costs and streamline business processes. If other companies also followed this procedure, the economy could fail because people who are unemployed do not have enough funds, thus the demand for goods and services is reduced, which can lead to business defaults. Similar findings emerged from a study conducted in the United Kingdom. According to this study, more than 10 million Britons are expected to be at risk of being replaced by robots over approximately 15 years. Artificial intelligence potentially threatens up to $30 \%$ of jobs 
(Mat'ovčíková, 2017). The fourth industrial revolution is expected to result in the transformation of approximately seven million jobs, which will be replaced by robots. It is estimated that businesses will replace approximately two million people with machines and robots. People who lose their jobs as a result of digitization will try to find employment in another profession or seek work from another employer. However, in many cases these people lose their jobs because of a lack of digital literacy, so they will act as an unskilled labor force in the labor market (Buchláková, 2016).

In this period, the Slovak Republic has significant opportunities for continuing the positive trend of growth of the surveyed indicators. It is therefore necessary to reassess research and development expenditure as well as education expenditure. Education is an opportunity to keep the economy competitive under the new conditions of Industry 4.0. This requires a fundamental reform of the education system, education methods and the creation of new curricula in line with labor market needs. The skills and knowledge developed so far in the Slovak education system in the future will be insufficient and new direction is required. This process with under-funded expenditure on science, research and education will not be possible. Although the share of expenditure on education is almost at the level of advanced economies, in the case of absolute expenditure, these are several times lower. The above conclusions also do not take into account the influence of external factors on economic development in the form of natural disasters, military interventions, health risks of the population. The current situation in Slovakia and in the world confirms our conclusions that, despite the positive trends in the development of the economy, it is necessary to continue in the field of digital skills of the workforce. The effects on increasing the efficiency of the economy through the Industry 4.0 concept are evident.

Monitoring the development of trends in the macroeconomic performance of economies under the influence of Industry 4.0 requires further research to be carried out as part of our scientific project.

\section{ACKNOWLEDGEMENT}

This study was created in the frame of the project VEGA 1/0462/20 "Vyhodnotenie zmien v kvalitatívnej štruktúre medzinárodných ekonomických vzt’ahov pod vplyvom Industry $4.0 \mathrm{~s}$ implikáciou na hospodárske politiky EÚ a SR“.

\section{REFERENCES}

Daugeliene, R. (2007). The position of knowledge workers in knowledge-based economy: migration aspect. European Integration Studies, 1, 103-112

Favell, A. (2014). The fourth freedom: Theories of migration and mobilities in 'neo-liberal' Europe. European Journal of Social Theory, Vol. 17, (3), 275-289

Hatemi-j, A., Ajmi, A. N., El Montasser, G., Inglesi-Lotz, R., \& Gupta, R. (2016). Research output and economic growth in g7 countries: New evidence from asymmetric panel causality testing. Applied Economics, 48(24), 2301-2308.

Hiete, M., Ludwig, J., \& Schultmann, F. (2012). Intercompany Energy Integration. In: Journal of Industrial Ecology, Vol. 16, Issue 5, 689-698.

Hozdic, E. (2015). Smart factory for Industry 4.0: A review. International Journal of Modern Manufacturing Technologies, 7 (1), 28-35.

Ivanová, E., \& Masárová, J. (2018). Performance evaluation of the Visegrad Group countries. Economic ResearchEkonomska Istrazivanja, 2018, 31 (1), 270-289

Kordoš, M., \& Vojtovič, S. (2016). Transnational corporations in the global world economic environment. 3rd International Conference on New Challenges in Management and Organization. Dubai, U Arab EmiratesI. Book Series: Procedia Social and Behavioral Sciences, Vol. 230, 150-158

Lisý, J. et al. (2011). Ekonómia. Wolters Kluwer (Iura Edition),Bratislava. 714 
Lisý, J. et al. (2005). Ekonómia v novej ekonomike. Iura Edition,Bratislava. 624

Mat'ovčíková, D. (2017). Industry 4.0 as the Culprit of Unemployment. In: 12th IWKM 2017. Available at: http://www.cutn.sk/Library/proceedings/km_2017/PDF_FILES/09_Matovcikova-71-78.pdf

Niková, K. (2018). Vplyv priemyslu 4.0 na vzdelávanie. In: EDTECH KISK, Masaryk University. Available at: https://medium.com/edtech-kisk/vplyv-priemyslu-4-0-na-vzdel\%C3\%A1vanie-38976bb1d6ac

Uramová, M., Lacová, Ž., \& Hronec, M. (2010). Makroekonómia I, Univerzita Mateja Bela, Ekonomická fakulta v Banskej Bystrici. 275 p.

Pinzone, M., Fantini, P., Garavaglia S., Taisch, M., \& Miragliotta, G. (2017). Jobs and Skills in Industry 4.0: An Exploratory Research. In: Advances in Production Management Systems. The path to intelligent, collaborative and sustainable manufacturing . Springer.. vol. 513, 282-288.

Rievajová E. (2017). Trh práce a politika zamestnanosti. Ekonomická univerzita, Bratislava. 207 p.

Slama, D., Puhlmann, F., Morrish, J., \& Bhatnagar, R. M. (2016). Enterprise IoT: Strategies and best practices for connected products and services. Sebastopol, California: O'Reilly Media, $464 \mathrm{p}$.

Slusarczyk, B. (2018). Industry 4.0 - Are we ready? In: Polish Journal of Management Studies, 17(10), $232-248$. https://doi.org/10.17512/pjms.2018.17.1.19

Solarin, S. A., \& Yen, Y. Y. (2016). A global analysis of the impact of research output on economic growth. Scientometrics, 108(2), 855-874.

Zaccaria, A., Cristelli, M., Kupers, R., Tacchella, A., \& Pietronero, L. (2016). A case study for a new metrics for economic complexity: The Netherlands. In: Journal of Economic Interaction and Coordination, 11(1), 151-169.

Záležaková, E. (2018). Manažment podnikania a vecí verejných. In: Industry Output 4.0, 13(7), 1-9.

Zezulka, F, Marcon, P., Veselý, I., \& Sajdl, O. (2016). Industry 4.0 - An Introduction to the phenomenon. IFACPapersOnLine, 49, 8-12. 